\title{
Dampak Penghasilan Istri pada Kepuasan Pernikahan Dewasa
}

\author{
Pingkan C. B. Rumondor, Greta Vidya Paramita, \\ Nangoi Priscilla Francis, Putri Lenggo Geni \\ Universitas Bina Nusantara \\ Jl. Kemanggisan Ilir III No. 45, Kemanggisan -Palmerah, Jakarta \\ prumondor@binus.edu,gretavidya@binus.edu, \\ priscilla@binus.edu,pl.geni@yahoo.com
}

\begin{abstract}
The current study aims to assess the effect of wife income to marital satisfaction among dual career young urban couples. Marital satisfaction is defined as a individual's subjective experience toward marriage or components within a marriage. The scale consists of 38 items measuring individual's satisfaction in communication, division in roles, agreement, openness, intimacy, intimacy in social relationship, sexuality, finance, and spirituality. The results indicate that the instrument was found to be reliable $(\alpha=0.967)$ and show correlation with subjective rating of overall marital satisfaction $\left(\mathrm{r}_{\mathrm{p}}=0.293, \mathrm{p}<0.05\right)$. The result come up from the study showed no effect of wife income to marital satisfaction in dual career young urban couples ( $\mathrm{p}>0.05)$.
\end{abstract}

Keywords: Marital satisfaction, young adult, dual career couples, wife's income,

\begin{abstract}
Abstrak-Penelitian ini ditujukan untuk melihat dampak dari penghasilan istri terhadap kepuasan pernikahan. Kepuasan pernikahan didefinisikan sebagai pengalaman subjektif individu terhadap pernikahan dan komponen-komponen dalam pernikahan. Pengukuran kepuasan pernikahan menggunakan skala Kepuasan Pernikahan Pasangan Urban yang dikonstruk oleh peneliti. Bentuk akhir dari skala ini terdiri dari 38 butir soal yang mengukur kepuasan individu dalam dimensi komunikasi, keseimbangan pembagian peran, kesepakatan, keterbukaan, keintiman, keintiman sosial dalam relasi, seksualitas, finansial, dan spiritualitas. Hasil analisis menunjukkan bahwa alat ukur ini reliabel $(\alpha=0.967)$ dan memiliki korelasi dengan penilaian subjektif mengenai kepuasan pernikahan secara keseluruhan $\left(r_{p}=0.293, p<0.05\right)$. Hasil penelitian ini didapatkan bahwa tidak terdapat perbedaan kepuasan pernikahan dewasa muda bila ditinjau dari tingkat penghasilan istri $(p>0.05)$.
\end{abstract}

Kata kunci: Kepuasan pernikahan, pasangan dewasa muda bekerja, pendapatan istri 


\section{PENDAHULUAN}

Pasangan yang menikah tentunya ingin memiliki pernikahan yang berkualitas, yakni pernikahan yang bertahan lama dan memuaskan bagi kedua belah pihak. Konstruk kualitas pernikahan ini terkait erat dengan kepuasan pernikahan dan penyesuaian pernikahan. Kedua konstruk tersebut sulit dikonseptualisasikan dan sulit diukur melalui penelitian empiris. Walaupun begitu, kedua hal tersebut penting diteliti karena kepuasan pernikahan dan penyesuaian pernikahan terkait dengan 50\% tingkat perceraian di Amerika, stres individu, kesehatan fisik, bahkan kesejahteraan psikologis anak (Lawrence, 2009). Kepuasan pernikahan (marital satisfaction) merujuk pada sikap secara umum terhadap pernikahan, atau kebahagiaan pernikahan sebagai suatu kesatuan konstruk. Sementara penyesuaian pernikahan (marital adjustment) memiliki cakupan yang lebih luas, mencakup proses-proses dalam pernikahan seperti kemampuan manajemen konflik, kegiatan saling mendukung, relasi seksual, atau keintiman emosional (Lawrence, 2009).

Konsep kepuasan pernikahan ini menjadi relevan dalam situasi di mana perceraian menjadi permasalahan yang marak, seperti di Indonesia, khususnya di Jakarta. Data Direktorat Jendral Badan Peradilan Agama Mahkamah Agung (Diitjen Badilag MA) pada tahun 2010 sebagaimana dilaporkan Saputra (2011) memperlihatkan ada 285.184 perkara yang berakhir dengan perceraian ke Pengadilan Agama se-Indonesia. Angka tersebut merupakan angka tertinggi sejak 5 tahun terakhir. Dari data tersebut, terdapat beberapa aspek yang menjadi pemicu perceraian. Terdapat 91.841 perkara karena masalah ketidakharmonisan dalam rumah tangga; 67.891 kasus karena masalah ekonomi, dan 10.029 kasus karena masalah cemburu (Saputra, 2011). Data terkini dari Pengadlian Agama Jakarta Selatan mencatat ada 2.102 gugatan cerai yang diputuskan selama tahun 2012 (Pengadilan Agama Jakarta Selatan, 2012). Data tersebut memperlihatkan bahwa ketidakharmonisan dalam rumah tangga dan masalah ekonomi berperan penting dalam menentukan suatu pernikahan akan bertahan atau berakhir dalam perceraian. Pengalaman praktek Sadarjoen (2012) sebagai psikolog perkawinan selama 10 tahun, yang dituangkan dalam modul Tata Laksana Couple Therapy mendukung informasi bahwa masalah terkait keuangan merupakan salah satu area utama dalam konflik perkawinan.

Salah satu masalah keuangan yang spesifik ialah kecenderungan suami tidak menyerahkan penghasilan pada istri karena merasa istri memiliki uang sendiri dari hasil kerjanya.Masalah keuangan lain yang juga mempengaruhi kebahagiaan seseorang dalam pernikahannya ialah kesulitan keuangan. Kesulitan keuangan ini bisa menyebabkan stres pada suami dan istri sehingga menimbulkan konflik di dalam pernikahan (Conger, Rueter, dan Elder, 1999). Salah satu cara mengatasi kesulitan keuangan ini ialah dengan penghasilan yang didukung oleh istri. Seiring dengan perkembangan zaman dan emansipasi wanita, selama dua dekade terakhir ini diperkirakan jumlah tenaga kerja wanita terserap di sektor industri sebagai buruh mengalami kenaikan sekitar 4,3\% setiap tahunnya (Tjaja, 2000). Selain itu, data Survei Tenaga Kerja Nasional (2008) memperlihatkan bahwa selama periode 2006-2008 peningkatan jumlah angkatan kerja perempuan jauh lebih besar dibandingkan dengan peningkatan jumlah angkatan kerja laki-laki. BPS Provinsi DKI Jakarta dalam Berita Resmi Statistika (2011) juga mencatat bahwa pada bulan Februari 2012 terjadi peningkatan jumlah wanita bekerja dibandingkan tahun sebelumnya. Fakta mengenai peningkatan angkatan kerja wanita ini dapat berdampak pada kualitas hidup dan pernikahan wanita yang bekerja.

Kondisi di mana istri bekerja merupakan cara mengatasi kesulitan keuangan keluarga. Tempat kerja pun memberikan dukungan pada pasangan bekerja, misalnya kebijakan jam kerja yang fleksibel, seminar mengenai keseimbangan kerja-keluarga, dan tunjangan untuk anak (Hammer, Neal, Newson, Brockwood, 
Olton, 2005). Namun penelitian longitudinal Hammer,dkk (2005) memperlihatkan bahwa semakin banyak seorang istri menggunakan dukungan di tempat kerja maka semakin tinggi konflik antara keluarga dan pekerjaan pada istri.

Berdasarkan data di atas, maka pasangan di mana suami dan istri sama-sama bekerja (dual-earner couple) memiliki dinamika yang khas. Di satu sisi, tambahan penghasilan dari pihak istri bisa membantu ekonomi keluarga. Di sisi lain, kondisi suami dan istri bekerja juga memperbesar kemungkinan terjadinya konflik di dalam keluarga terkait dengan pekerjaan. Konflik yang berlanjut dapat menyebabkan penurunan kepuasan pernikahan seseorang. Oleh karena itu, penelitian ini ingin melihat kepuasan pernikahan pada pasangan yang bekerja. Secara khusus, penelitian ini ingin melihat dampak penghasilan istri pada kepuasan pernikahan. Dampak ini diteliti dengan melihat perbedaan kepuasan pernikahan pada tiga kelompok, yaitu pasangan dengan penghasilan istri lebih dari penghasilan suami, penghasilan istri sama dengan penghasilan suami, dan penghasilan istri lebih kecil dari penghasilan suami.

Hal ini penting diteliti karena kepuasan pernikahan terkait dengan kualias hidup (psychological wellbeing) dan kesehatan individu. Hal ini terbukti dalam penelitian Shek (1995) pada 1.501 pasangan menikah di Cina dan studi meta analisis oleh Proulx, Helms, Buehler (2007) yang mendapatkan hubungan erat antara kualitas pernikahan dan well-being seseorang. Selain merupakan peristiwa sosial, pernikahan memberikan keuntungan bagi individu yang ada di dalamnya, baik laki-laki maupun perempuan. Dalam sebuah studi longitudinal, ditemukan bahwa individu yang menikah memiliki resiko kematian lebih rendah, dibandingkan kelompok individu yang belum pernah menikah atau bercerai (Waite dan Gallagher, 2000, dalam Howe, 2012). Hal ini didukung dengan penelitian lain di Amerika yang menemukan bahwa manfaat kesehatan dari pernikahan lebih besar bagi pria daripada bagi wanita, di mana perlindungan terhadap kematian 50\% lebih tinggi bagi wanita yang menikah, tetapi $250 \%$ lebih tinggi untuk laki-laki yang menikah (Robles dan Kiecolt-Glaser, 2003, dalam Howe, 2012). Hal yang menjadi penekanan ialah manfaat positif pernikahan ini baru akan terlihat ketika pernikahan yang dijalani ialah pernikahan yang bahagia atau memuaskan. Sebaliknya, individu dalam pernikahan yang tidak bahagia menunjukkan kondisi kesehatan yang buruk. Penelitian Coontz (2005, dalam Howe, 2012) menunjukkan bahwa individu yang memiliki tekanan darah tinggi tetapi berada dalam pernikahan bahagia menunjukkan penurunan tekanan darah saat menghabiskan beberapa menit bersama pasangannya, sebaliknya individu dalam pernikahan tidak bahagia menunjukkan peningkatan tekanan darah saat menghabiskan beberapa menit bersama pasangannya.

Selain berdampak pada pasangan, kebahagiaan dan keutuhan pernikahan akan berdampak baik pada keluarga terkait hingga masyarakat pada umumnya. Gallagher (2003) menyatakan bahwa menurut suatu penelitian di Amerika, anak akan memiliki kehidupan lebih baik jika dibesarkan oleh kedua orangtuanya. Anak cenderung memiliki tingkat kehidupan yang lebih lama, tingkat kesehatan yang lebih tinggi dan tingkat gangguan mental yang lebih rendah, mengalami kemiskinan, kejahatan dan kekerasan domestik lebih jarang serta memiliki hubungan interpersonal yang hangat jika kedua orangtuanya tetap berada dalam pernikahan.

Dalam penelitian ini, kepuasan pernikahan (marital satisfaction) dilihat sebagai penilaian secara umum terhadap pernikahan, atau kebahagiaan pernikahan sebagai suatu kesatuan konstruk. Konstruk yang juga sejalan dengan kepuasan pernikahan ialah penyesuaian pernikahan. Penyesuaian pernikahan (marital adjustment) memiliki cakupan yang lebih luas, mencakup proses-proses dalam pernikahan seperti kemampuan manajemen konflik, kegiatan saling mendukung, relasi seksual, atau keintiman emosional (Lawrence, 2009). Kepuasan pernikahan dapat diukur antara lain dengan ENRICH marital satisfaction (Fowers dan Olson, 1993) dan Kuesioner Kepuasan Pernikahan (Sadarjoen, 2004). Sementara, penyesuaian pernikahan diukur melalui 
penyesuaian diadik (dyadic adjustment) yang dicetuskan Spanier (1976). Spanier (1976) mendefinisikan penyesuaian diadik sebagai proses yang bergerak dalam kontinum yang dapat dievaluasi sebagai penyesuaian yang baik atau penyesuaian yang buruk.

\section{Tinjauan Teoritis}

\section{Kepuasan Pernikahan}

Menurut Atwater dan Duffy (2005), kepuasan pernikahan merupakan perasaan menyenangkan dan puas dalam pernikahan. Sementara Fowers dan Olson (1993) melihat kepuasan pernikahan sebagai kepuasan yang mencakup kepuasan terhadap keseluruhan pernikahan, kepuasan akan faktor spesifik terkait idealistic distortion, isu kepribadian, komunikasi, resolusi konflik, pengaturan keuangan, hubungan seksual, pengasuhan anak, hubungan dengan teman dan keluarga, peran yang seimbang serta orientasi religius. Penelitian lain merangkum faktor-faktor yang terkait dengan kepuasan pernikahan seseorang di antaranya adalah (1) waktu, yang terbagi menjadi tiga hal yaitu lama berpacaran (Grover,dkk. 1985 dalam Lauer dan Lauer, 2000), usia (Robert Bitter, 1986 dalam Lauer dan Lauer, 2000), dan kesiapan untuk menikah (Holman dan Li, 1997 dalam Lauer dan Lauer, 2000), (2) kesetaraan dalam hubungan dan tanggung jawab dalam pekerjaan rumah tangga (Davidson 1984 dan Suitor 1991, dalam Lauer dan Lauer, 2000), dan (3) komunikasi (Goleman, 1985, dalam Lauer dan Lauer, 2000). Faktor lain yang menentukan kepuasan pasangan dalam suatu pernikahan yaitu penyesuaian.

Menurut Atwater dan Duffy (2005) penyesuaian pernikahan ialah perubahan dalam hubungan pasangan selama berjalannya pernikahan. Sejalan dengan definisi tersebut, DeGenova (2005) mendefinisikan penyesuaian pernikahan sebagai proses memodifikasi, beradaptasi dan mengubah pola perilaku dan interaksi pasangan maupun individu untuk mencapai kepuasan maksimun dalam hubungan. Lebih jauh, Lawrence (2009) memaparkan proses-proses dalam penyesuaian pernikahan antara lain keterampilan manajemen konflik dan konsekuensi dari pernikahan, seperti halnya kepuasan pernikahan.

Kepuasan pernikahan merupakan konstruk yang dipengaruhi oleh konteks budaya. Penelitian kualitatif yang dilakukan Wong dan Goodwin (2009) lintas tiga budaya, yaitu Inggris, Hong Kong dan Beijing, memperlihatkan bahwa ketiga konteks budaya tersebut, melihat stabilitas hubungan, dukungan pasangan, kerja sama dengan pasangan, dan keuangan keluarga yang stabil sebagai faktor penting yang menentukan kepuasan pernikahan. Selain persamaan, tiga konteks budaya tersebut memiliki penekanan yang berbeda mengenai kepuasan pernikahan. Responden di Inggris leboh mementingkan companionship, sementara responden di Hong Kong lebih menekankan hubungan yang harmonis.

\section{Pengukuran Kepuasan Pernikahan}

Penelitian sebelumnya melahirkan beberapa alat ukur kepuasan pernikahan. Salah satu yang dinilai memiliki kualitas psikometri paling baik ialah DAS yang dikembangkan Spanier (1976). Sementara salah satu yang sering digunakan dalam penelitian ialah ENRICH yang dikembangkan Fowers dan Olson (1993). Spanier (1976) mengembangkan Dyadic Adjustment Scale yang terbagi menjadi empat sub skala, yaitu dyadic consensus, dyadic satisfaction, dyadic cohesion, dan affectional expression. Sementara ENRICH marital satisfaction scale (Fowers dan Olson 1993) terdiri dari 12 kategori yaitu idealistic distortion, marital satisfaction, personality issues, communication, conflict resolution, financial management, leisure 
activities, sexual relationship, children and parenting, family and friends, equalitarian roles, dan religious orientation.Pengukuran kepuasan pernikahan di Indonesia, khususnya pada pasangan eksekutif muda di kawasan perkotaan dibuat oleh Sadarjoen (2004) yang terdiri dari 7 aspek kepuasan yaitu emosi, seksual, intelektual, finansial, spiritual, rekreasi, dan keintiman sosial dalam relasi sosial.

\section{METODE}

\section{Partisipan}

Partisipan dari penelitian ini ialah 100 orang individu dewasa muda (33\% laki-laki, 67\% perempuan), rentang usia 24 hingga 40 tahun $(M=31.17, S D=4)$ yang sudah menikah dengan usia pasangan antara 23 hingga 40 tahun $(M=31.12, S D=4)$, bekerja dan memiliki pasangan bekerja pula. Semua pasangan berada dalam fase 1 hingga 5 tahun perkawinan $(\mathrm{M}=2.9$. $\mathrm{SD}=1.28)$, yang identik dengan masa adaptasi dan penyesuaian (Sadarjoen, 2012). Partisipan berdomisili di wilayah Jabodetabek dan bekerja di Jakarta. Sampel dalam penelitian ini diperoleh secara non-probability sampling, khususnya yang dipakai ialah convenience sampling.

Tingkat pendidikan partisipan paling banyak berada pada taraf S1 (81\%) diikuti D3 (11\%) dan S2/ Profesi (8\%).Tingkat pendidikan partisipan tersebut memungkinkan mereka memahami isi kuesioner yang dibagikan. Penyebaran jenis pekerjaan partisipan menunjukkan bahwa sebagian besar partisipan memiliki pekerjaan sebagai karyawan (84\%) diikuti profesi guru (8\%) dan wirausahawan (8\%).

Rata-rata jarak rumah partisipan dengan kantor ialah $19 \mathrm{~km}$. Jarak tersebut ditempuh dalam waktu rata-rata 45.6 menit jika lalu lintas lancar dan ditempuh dalam waktu rata-rata 1 jam 18 menit saat lalu lintas padat. Jarak terjauh rumah dan kantor partisipan ialah $40 \mathrm{~km}$ dan waktu tempuh maksimal saat lalu lintas lancar ialah $2 \mathrm{jam}$. Waktu tempuh maksimal untuk situasi lalu lintas padat ialah 3 jam. Data ini menunjukkan kondisi jarak dan waktu tempuh rumah-kantor yang khas bagi pekerja yang tinggal daerah urban seperti Jakarta, Depok, Tangerang, Bekasi dan bekerja di Jakarta.

Tingkat penghasilan partisipan ialah sebagai berikut, $44 \%$ partisipan penelitian memiliki penghasilan antara 5 hingga 7 juta rupiah per bulan. Sementara 24\% menghasilkan 2.5 hingga 4.9 juta rupiah per bulan; 7\% menghasilkan 10-12 juta rupiah per bulan; 6\% menghasilkan kurang dari 2.5 juta; proporsi yang sama juga menghasilkan antara 7.5-9.9 juta rupiah; diikuti dengan penghasilan 15-17.4 juta rupiah sebanyak 4\%, sementara hanya 2\% partisipan dengan penghasilan per bulan antara 15-17.4 juta rupiah dan di atas 20 juta rupiah. Gambaran ini memperlihatkan bahwa partisipan berasal dari kalangan status sosial ekonomi menengah atas.

Berdasarkan data penelitian, didapati bahwa $52 \%$ partisipan masuk dalam kelompok tingkat penghasilan istri yang lebih kecil dari suami; sementara 36\% partisipan masuk dalam kelompok tingkat penghasilan istri sama dengan suami, serta hanya $12 \%$ partisipan masuk dalam kelompok tingkat penghasilan istri lebih besar dari suami.

\section{Desain}

Penelitian ini tergolong dalam desain ex post facto field studies atau penelitian non-eksperimental karena variabel yang diteliti merupakan sesuatu yang sudah terjadi dan tidak dapat dikontrol secara langsung 
(Seniati, Yulianto, dan Setiadi, 2005). Sementara berdasarkan tipe informasi yang diperoleh, penelitian ini termasuk penelitian kuantitatif. Data yang diperoleh dalam penelitian ini berupa angka yang akan dianalisis secara statistik (Seniati, Yulianto, dan Setiadi, 2005).

\section{Prosedur}

Pada tahap pertama, peneliti melakukan studi literatur dengan mengumpulkan artikel jurnal dan buku mengenai kepuasan pernikahan. Selanjutnya, peneliti menentukan alat ukur kepuasan pernikahan yang akan menjadi acuan. Setelah itu, peneliti melakukan wawancara awal pada 4 pasangan dewasa muda bekerja di Jakarta untuk menyesuaikan isi alat ukur tersebut dengan kondisi pasangan muda bekerja di kawasan urban.

Peneliti kemudian melakukan konstruksi dan uji coba Skala Kepuasan Pernikahan Pasangan Urban. Skala yang sudah diuji kemudian disebarkan kepada partisipan yang sesuai kriteria. Penyebaran skala dilakukan dengan mengirimkan tautan skala on-line, serta mengirimkan skala hard-copy pada rekan-rekan peneliti untuk diisi dan diberikan pada teman kantor mereka yang bersedia menjadi partisipan penelitian. Data kemudian dikumpulkan oleh asisten peneliti untuk diolah lebih lanjut.

\section{Alat Ukur}

Alat ukur yang dipakai untuk melihat kepuasan pernikahan pasangan dewasa muda di kawasan urban ialah Skala Kepuasan Pernikahan Pasangan Urban yang dikonstruk oleh tim peneliti. Skala Kepuasan Pernikahan Pasangan Urban ini dikembangkan dengan mengombinasikan dimensi dari tiga alat ukur yaitu Dyadic Adjustment Scale (Spanier 1976), ENRICH marital satisfaction (Fowers dan Olson, 1993) dan Kuesioner Kepuasan Pernikahan (Sadarjoen, 2004).

Peneliti melakukan beberapa penyesuaian dengan kondisi pasangan usia dewasa muda yang tinggal di wilayah perkotaan dengan cara mewawancarai empat pasangan suami-istri bekerja di Jakarta. Hasil wawancara menunjukkan terdapat 9 dimensi dalam kepuasan pernikahan pasangan yang tinggal dan bekerja di kawasan urban, yaitu:

1. Komunikasi

Pasangan puas akan cara yang khas untuk berkomunikasi satu sama lain. Pasangan dapat memahami maksud dari pasangannya dan merasa dipahami oleh pasangannya, termasuk dipahami dalam bidang pekerjaan/pendidikan yang ditekuni.

2. Keseimbangan pembagian peran

Pasangan puas dengan pembagian peran yang seimbang dalam pernikahan.

3. Kesepakatan

Pasangan mampu berdiskusi dengan setara dan ada satu orang yang lebih memahami situasi sehingga menjadi dominan dalam pengambilan keputusan sehingga mencapai kesepakatan.

4. Keterbukaan

Pasangan bersedia mengungkapkan informasi pribadi, isi pikiran dan perasaan secara terbuka, termasuk terbuka akan gaji dan perencanaan keuangan.

5. Keintiman

Pasangan dapat secara nyaman menghabiskan waktu untuk melakukan aktivitas bersama-sama, tanpa kehadiran pihak lain. 
6. Keintiman sosial dalam relasi

Pasangan nyaman melakukan kegiatan dalam lingkup sosial sebagai pasangan, seperti mengunjungi acara keluarga, atau membantu teman/kerabat yang memerlukan bantuan.

7. Seksualitas

Pasangan bebas menentukan aktivitas seksual, dari segi tempat, waktu untuk memenuhi kebutuhan seksualnya dan adanya kesetiaan untuk berhubungan seksual hanya dengan pasangannya saja.

8. Finansial

Pasangan dapat memenuhi kebutuhan finansial keluarga batihnya dari segi jumlah dan memiliki pembagian tanggung jawab finansial.

9. Spiritualitas

Pasangan merasakan pemenuhan kebutuhan spiritualitasnya tercukupi selama berada dalam ikatan pernikahan.

Penentuan dimensi dan butir soal dibantu dengan expertjudgement dengan Prof. Dr. Sawitri Sadarjoen dan Dr. Adriana Ginanjar, dua orang psikolog klinis dengan bidang keahlian pernikahan. Butir soal dirumuskan berdasarkan dimensi tersebut. Kuesioner awal yang digunakan terdiri dari 58 butir soal yang berupa skala Likert dengan empat kemungkinan jawaban yaitu "sangat sesuai", "sesuai", "kurang sesuai", dan "sangat tidak sesuai". Setelah melalui tahap uji coba tahap 1 dan revisi item, maka dilakukan perubahan bentuk pilihan jawaban, yaitu menjadi "sangat puas", "puas", "tidak puas", "sangat tidak puas".

Perubahan lain ialah jumlah soal menjadi 38 butir soal. Pada pengambilan data, didapat coefficient alpha cronbach $(\alpha)$ untuk skor total sebesar 0.967 . Selain itu didapat coefficient alpha cronbach $(\alpha)$ untuk masingmasing dimensi sebagai berikut: Komunikasi ( $\alpha=0.724)$, Keseimbangan Peran $(\alpha=0.818)$, Kesepakatan ( $\alpha=0.794)$, Keterbukaan $(\alpha=0.830)$, Keintiman $(\alpha=0.817)$, Keintiman Sosial dalam Relasi $(\alpha=0.773)$, Seksualitas $(\alpha=0.734)$, Finansial $(\alpha=0.822)$, Spiritualitas $(\alpha=0.924)$. Sementara, koefisien korelasi Pearson yang didapat memperlihatkan bahwa validitas kriterion yang signifikan $\left(\mathrm{r}_{\mathrm{p}}=0.293, \mathrm{p}<0.05\right)$. Hal ini memperlihatkan bahwa semakin tinggi skor total kuesioner kepuasan pernikahan maka semakin tinggi pula penilaian terhadap kepuasan subjektif secara keseluruhan. Dapat disimpulkan bahwa skala kepuasan pernikahan pada pasangan urban ini valid dalam memprediksi kepuasan pernikahan pasangan dewasa muda bekerja di Jakarta.

\section{Teknik Analisis}

Data yang telah dimasukkan ke dalam program SPSS diolah dengan menggunakan metode one-way ANOVA untuk melihat signifikansi perbedaan antara kelompok pasangan dengan penghasilan istri lebih besar dari suami, kelompok pasangan dengan penghasilan istri sama dengan suami, dan penghasilan istri lebih kecil dari penghasilan suami.

\section{ANALISIS \& HASIL}

Pengolahan data dengan metode one-way ANOVA menunjukkan tidak ada perbedaan kepuasan pernikahan yang signifikan $(p>0.05)$ pada pasangan dengan penghasilan istri lebih dari penghasilan suami, penghasilan istri sama dengan penghasilan suami, dan penghasilan istri lebih kecil dari penghasilan suami, 
$\mathrm{F}(2,97)=0.95, p=0.91$. Dengan kata lain, perbedaan tingkat penghasilan antara suami dan istri tidak berdampak pada kepuasan pernikahan dewasa muda di kawasan urban. Sebagian besar partisipan penelitian berada pada tingkat status sosial ekonomi menengah atas sehingga dapat disimpulkan bahwa perbedaan tingkat penghasilan suami dan istri tidak berdampak pada kepuasan pernikahan pasangan dalam status sosial ekonomi menengah atas.

Hasil penelitian ini juga mengimplikasikan bahwa ada hal lain yang berdampak pada kepuasan pernikahan seseorang. Tingkat penghasilan, sama seperti data demografis lainnya, bisa dilihat sebagai faktor eksternal yang penting bagi kepuasan pernikahan. Walaupun stabilitas finansial termasuk faktor yang penting dalam kepuasan pernikahan (Wong dan Goodwin, 2009), tetapi terdapat hal lain yang berdampak pada kepuasan pernikahan pasangan, terlebih berupa faktor internal. Salah satunya ialah cara coping permasalahan yang ada. Goei (2012) menyatakan bahwa berbagai penelitian menunjukkan bahwa coping diadik menyumbang 35\% varians dari kepuasan pernikahan. Penelitian pada 203 pasangan di Indonesia tersebut, memperlihatkan bahwa stres eksternal tidak memiliki pengaruh langsung terhadap coping diadik yang negatif, sementara stres eksternal akan mempengaruhi stres internal yang kemudian mempengaruhi coping diadik negatif.

Selain coping diadik, faktor lain yang juga bisa mempengaruhi kepuasan pernikahan adalah kondisi bahwa self esteem pasangan yang keduanya bekerja yang lebih tinggi dibandingkan pasangan yang suami merupakan satu-satunya pencari nafkah (Haas, 1999; Steil, 2009, dalam Weiten, Hammer, Dunn, 2012). Faktor lain yang juga terkait dengan kepuasan pernikahan ialah kejujuran dan komunikasi tentang pengelolaan keuangan serta kepuasan kerja (Howe, 2012). Namun, di dalam penelitian ini, peneliti belum dapat memberikan pembahasan yang mendalam, karena aspek komunikasi ekonomi belum secara khusus diperlakukan sebagai variabel dalam penelitian ini.

Penelitian ini juga memperlihatkan bahwa perbedaan tingkat penghasilan suami-istri tidak menjadi ancaman bagi kepuasan pernikahan seseorang. Analisis deskriptif dari kepuasan pernikahan keseluruhan partisipan penelitian menunjukkan skor rata-rata ialah $119.71(\mathrm{SD}=16.94)$ dan skewed negatif. Sementara analisis chi square menunjukkan tidak ada perbedaan kepuasan pernikahan pada kelompok istri dan suami, $\mathrm{X}^{2}(47, \mathrm{~N}=100)=51.116, p>0.05$. Dapat disimpulkan bahwa sebagian besar partisipan menilai pernikahan mereka sebagai memuaskan dan hal ini berlaku sama pada suami maupun istri. Hal ini mengimplikasikan bahwa pasangan dengan penghasilan ganda bahkan dapat memberikan efek yang positif pada kepuasan pernikahan, baik pada suami maupun istri. Efek positif dari pasangan yang keduanya bekerja ini terjadi saat saat pasangan saling menunjukkan dukungan, misalnya dengan mendengarkan keluhan, peka terhadap sudut pandang pasangan dan mampu mengekspresikan persetujuan akan kualitas pasangannya, seperti ditunjukkan dari penelitian Conger, Rueter, dan Elder (1999).

Selain itu, penelitian Coursolle dan Sweeney (2009, dalam Weiten, Hammer, Dunn, 2012), memperlihatkan bahwa dalam jangka panjang, peran ganda (kerja-keluarga) pada pasangan suami istri yang bekerja dapat juga memberikan efek positif. Efek positif ini didapatkan oleh karena mereka memiliki tambahan dukungan sosial, serta meningkatkan kesempatan mengalami kesuksesan. Kesuksesan yang dimaksudkan di sini adalah pada saat seseorang mengalami efek negatif dari stres pada salah satu aspek peran di pekerjaan/ rumah tangga, efek negatif tersebut dapat diminimalisir dengan kesuksesan di peran yang lain. Selain itu, saat kedua pasangan bekerja, individu cenderung dapat menemukan kesamaan di antara mereka (Barnett dan Hyed, 2001, dalam Weiten, dkk., 2012). 


\section{DISKUSI}

Hasil penelitian ini sejalan dengan penelitan longitudinal dari Brennan, Barnet, Gareis (2001) yang meneliti pasangan dengan dua penghasilan. Penelitian tersebut mendapati bahwa perubahan pendapat istri yang relatif lebih tinggi dari suami, dari waktu ke waktu tidak berdampak signifikan pada evaluasi mereka terhadap kualitas hubungan pernikahan. Hal ini berlaku juga pada penelitian ini, di mana sebagian besar responden adalah istri.

Terlepas dari hasil yang didapat, penelitian ini memiliki beberapa keterbatasan. Antara lain, unit analisis dari penelitian ini adalah individu, belum melihat pasangan sebagai satu unit. Selain itu, sampel penelitian ini juga tergolong sedikit dan terbatas pada area urban, di Jakarta. Oleh karena itu, penelitian selanjutnya dapat meneliti lebih lanjut mengenai kepuasan pernikahan pada pasangan sebagai unit analisis, dengan sampel lebih banyak dan melibatkan area urban lain di Indonesia.

\section{SIMPULAN \& SARAN}

Hasil penelitian ini menunjukkan bahwa tidak terdapat perbedaan kepuasan pernikahan yang signifikan pada pasangan dengan penghasilan istri lebih besar dari suami, penghasilan istri sama dengan suami dan penghasilan istri lebih kecil dari suami. Hal-hal lain yang mempengaruhi tidak adanya perbedaan kepuasan pernikahan pada pasangan bekerja yang ditinjau dari penghasilan istri adalah bagaimana kemampuan pasangan dalam melakukan coping diadik saat mengalami stres internal maupun eksternal, serta dukungan pasangan dan kemampuan menyetujui kualitas pasangan. Selain itu, aspek komunikasi mengenai finansial, tingkat stres di pekerjaan, serta ideologi peran gender perlu menjadi perhatian sebagai salah satu variabel dalam penelitian kepuasan pernikahan pada pasangan bekerja selanjutnya.

Hasil penelitian ini dapat digunakan sebagai bahan pertimbangan wanita dewasa muda yang ingin bekerja setelah menikah. Tidak ditemukannya perbedaan kepuasan pernikahan yang signifikan pada pasangan dewasa muda yang bekerja, ditinjau dari penghasilan istri, mengindikasikan bahwa istri dapat bekerja dan menghasilkan penghasilan lebih dari suami tanpa mempengaruhi kepuasan pernikahan mereka. Pada sisi lain, pasangan dewasa muda yang bekerja disarankan memperhatikan faktor-faktor lain yang dapat mempengaruhi kepuasan pernikahan mereka, misalnya seperti coping diadik, dukungan terhadap pasangan, dan komunikasi mengenai finansial.

\section{UCAPAN TERIMA KASIH}

Peneliti berterima kasih kepada Panitia 3rd Urban Mobility Conference, Universitas Airlangga yang memberikan kesempatan mempresentasikan hasil uji coba alat ukur Kepuasan Pernikahan Pasangan Urban yang digunakan dalam penelitian ini di 3th Urban Mobility Conference pada 8 Desember 2012. Artikel yang dipresentasikan juga diterbitkan dalam Prosiding Urban dalam Wacana: Kesehatan, Budaya dan Masyarakat, dengan judul "Kepuasan Pernikahan dan Penghasilan Pasangan Dewasa Muda di Kawasan Urban: Sebuah Studi Awal'. Dalam artikel ini, sebagian isi artikel tersebut dicantumkan pada bagian alat ukur. 


\section{DAFTAR PUSTAKA}

Atwater, E., \& Duffy, K. G. (2005). Psychology for Living: Adjustment, Growth, and Behavior Today (7th ed.). New Jersey: Prentice-Hall, Inc.

Brennan, R.T., Barnett, R. C., Gareis, K. C. (2001). When She Earns More Than He Does: A longitudinal Study of Dual-Earner Couples. Journal of Marriage and Family, Vol. 63, 168-182.

Conger, R. D., Rueter, M. A., \& Elder, G. H., Jr. (1999). Couple Resilience to Economic Pressure. Journal of Personality and Social Psychology, Vol. 76, 54-71.

DeGenova, M. K. (2005). Intimate relationships, Marriage and Families. Boston: McGraw-Hill.

Fowers, B. J., Olson, D. H. (1993). ENRICH Marital Satisfaction Scale: A Brief Research and Clinical Tool. Journal of Family Psychology, Vol. 7, No. 2, p. 176-185.

Goei, Y. A. (2012). Pengaruh Stres Internal dan Stres Eksternal pada Coping Diadik Negatif. Jurnal Psikologi Ulayat, Vol. 1, No. 1/Oktober 2012, hlm. 119-130.

Howe, T. R. (2012). Marriages and Families in The $21^{\text {st }}$ Century: A Bioecological Approach. West Sussex: Wiley-Blackwell.

Hammer, L. B., Neal, B. M., Newsom, J. T., Brockwood, K. J., Colton, C. L. (2005). A longitudinal study of the effects of dual earner couple's utilization of family-friendly workplace support on work and family outcomes. Journal of Applied Psychology, Vol. 90, No. 4, 799-810.

Lauer, R. H., Lauer, J. C. (2000). Marriage \& Family: The Quest for Intimacy 4th Ed. Boston: McGraw-Hill.

Proulx, C. M., Helms, H. M., Buehler, Cheryl. (2007) Marital quality and personal well-being: a metaanalysis. Journal of Marriage and Family, Vol. 69, 576-593.

Sadarjoen, S. S. (2004). Model Kualitas Perkawinan Berdasarkan Kepegasan Pasangan dan Gaya Penyelesaian Konflik Perkawinan: Studi Eksplanatif terhadap Pasangan Perkawinan Eksekutif Muda Pada Usia Perkawinan Sepuluh Tahun Pertama di Kota Bandung dan Jakarta. Doctoral Disertation. Bandung: Universitas Padjajaran.

Sadarjoen, S. S. (2012). Modul Tata Laksana Couple Therapy Universitas Yarsi. Jakarta: Modul, tidak diterbitkan.

Seniati, A. N. L., Yulianto, A., Setiadi, B. N. (2005). Psikologi Eksperimen. Jakarta: PT Indeks.

Weiten, W., Hammer, E. Y., Dunn, D. S. (2012). Psychology and Contemporary Life: Human Adjustment. $\left(10^{\text {th }}\right.$ Ed). Singapura: Wadsworth Cengage Learning.

Wong, S. \& Goodwin, R. (2009). Experiencing marital satisfaction across three cultures: A qualitative study. Journal of Social and Personal Relationships. Vol. 26, No. 8., pp. 1011-1028.

\section{Internet}

Berita Resmi Statistika (BPS). (2011). Keadaan ketenagakerjaan di DKI Jakarta Februari 2011. Diunduh dari http://jakarta.bps.go.id/fileupload/brs/2011_08_05_12_41_59.pdf

Gallagher, M. (2003). Why Marriage Matters: The Case for Normal Marriage. Testimony before the U.S. Senate Subcommittee on the Constituion, Civil Rights, and Property Rights Hearing: "What is Needed 
to Defend the Bipartisan Defense of Marriage Act of 1996?'. Diunduh tanggal 15 Februari 2013 dare http://www.marriagedebate.com/pdf/SenateSept42003.pdf.

Lawrence, E., dkk. (2009). "Marital Satisfaction, Assesment of”. Encyclopedia of Human Relationships. SAGE Publications. Diunduh tanggal 3 April 2010 dari http://www.sage-ereference.com/humanrelationships/ Article_n330.html.

Saputra, Andi. (2011). Pemicu utama Perceraian Masalah Ekonomi, Selingkuh Urutan Kedua. Diunduh tanggal 30 Januari 2012 dari http://www.detiknews.com/read/2011/08/03/113811/1695407/10/pemicuutama-perceraian-masalah-ekonomi-selingkuh-urutan-kedua?nd9922

Shek, D. T. L. (1995). Marital quality and psychological well-being of married adults in a chinese context. The Journal of Genetic Psychology, 156 (1), 45-45. Retrieved from http://search.proquest.com/docv iew $/ 228502284$ ? accountid $=31532$

Survey Tenaga Kerja Nasional. (2008). Partisipasi Angkatan Kerja. Diunduh tanggal 30 Januari 2012 dari http://www.menegpp.go.id/aplikasidata/index.php?option=com_docman\&task=doc download\&gid $=306 \&$ Itemid $=65$

Tjaja, R. P. (2000). Wanita Bekerja dan Implikasi Sosial. Naskah. No. 20./Juni-Juli 2000. Diunduh tanggal 30 Januari 2012 dari http://www.bappenas.go.id/get-file-server/node/8632. 
